\title{
ANALISA BIAYA PEMBANGKITAN PEMBANGKIT LISTRIK TENAGA PANAS BUMI SKALA KECIL
}

\author{
Abdul Hamid Budiman ${ }^{*}$ dan Akim Windaru \\ Balai Besar Teknologi Konversi Energi - Badan Pengkajian dan Penerapan \\ Teknologi \\ Gedung 621, Klaster Energi, Kawasan Puspiptek - Serpong \\ Tangerang Selatan 15413 \\ "Email: hamid.budiman@bppt.go.id
}

\begin{abstract}
The potency of geothermal in Indonesia is very huge. However, its development is still low. The location is usually isolated and leads to the economical point of view that is not competitive. This paper describes generating cost of small-scale geothermal power plant using three scenarios those are Business as Usual (BAU), Local Content (TKDN) and Clean Development Mechanism (CDM). The study shows that the average generating cost of geothermal power plant is 15.50 cent $\$ / \mathrm{kWh}$ for BAU, 14.36 cent $\$ / \mathrm{kWh}$ for TKDN, 14.65 cent $\$ / \mathrm{kWh}$ for CDM and 13.51 cent $\$ / \mathrm{kWh}$ for all scenarios combined. It shows that generating cost of small-scale geothermal power plant is more competitive than small-scale diesel power plant which has generating cost of 17.20 cent $\$ / \mathrm{kWh}$.
\end{abstract}

Key words: Small-scale Geothermal Power Plant, Generating Cost, Business as Usual, Local Content, Clean Development Mechanism

\begin{abstract}
Abstrak
Potensi panas bumi di Indonesia sangat besar. Namun demikian pengembangan panas bumi di Indonesia masih rendah. Salah satu kendala yang banyak dihadapi dalam pengembangan energi panas bumi saat ini adalah letaknya yang terisolir jauh dari beban, sehingga menyebabkan tingkat keekonomianya kurang menarik. Tulisan ini menjelaskan biaya pembangkitan dari Pembangkit Listrik Tenaga Panas Bumi (PLTP) skala kecil menggunakan tiga skenario yaitu Business as Usual (BAU), Tingkat Kandungan Dalam Negeri (TKDN) dan Clean Development Mechanism (CDM). Hasil studi menunjukkan biaya pembangkitan rata-rata untuk PLTP skala kecil adalah 15,5 cent $\$ / \mathrm{kWh}$ untuk skenario BAU, 14,36 cent $\$ / \mathrm{kWh}$ untuk skenario TKDN, 14,65 cent $\$ / \mathrm{kWh}$ untuk skenario CDM dan 13,51 cent $\$ / \mathrm{kWh}$ untuk skenario gabungan. Dibanding dengan Pembangkit Listrik Tenaga Disel (PLTD), PLTP skala kecil masih lebih kompetitif, dimana biaya pembangkitan PLTD skala kecil adalah 17,20 cent $\$ / k W h$.
\end{abstract}

\section{Kata kunci: PLTP Skala Kecil, Biaya Pembangkitan, BAU, TKDN, CDM}

\section{PENDAHULUAN}

Ketersediaan energi listrik merupakan elemen yang sangat penting dalam berbagai aspek kehidupan manusia. Selain itu, energi listrik juga merupakan kebutuhan mutlak untuk menunjang pembangunan nasional yang berkelanjutan. Hal ini menjadi tantangan besar bagi Indonesia ketika dihadapkan pada kondisi dimana sebagian besar penyediaannya masih bergantung pada energi fosil dan pengembangan sumber-sumber energi terbarukan masih sangat terbatas.

Penggunaan energi di Indonesia meningkat pesat sejalan dengan pertumbuhan ekonomi dan pertambahan penduduk. Namun demikian akses ke energi yang andal dan terjangkau belum bisa sepenuhnya dinikmati oleh masyarakat.

Di sisi lain, potensi energi terbarukan seperti panas bumi cukup besar. Hanya saja sampai 
saat ini pemanfaatannya masih sangat terbatas. Hal ini antara lain disebabkan oleh harga energi terbarukan yang belum kompetitif bila dibandingkan dengan harga energi fosil, penguasaan teknologi yang rendah, keterbatasan dana untuk penelitian dan pengembangan maupun investasi dalam pemanfaatan energi terbarukan serta infrastruktur yang kurang memadai.

Panas bumi sebagai salah satu sumber daya energi terbarukan mempunyai potensi yang berlimpah di Indonesia. Meskipun saat ini belum dimanfaatkan secara optimal, namun Pemerintah saat ini mulai memberikan perhatian yang serius. Hal ini terlihat dengan adanya target pemerintah yang cukup ambisius, yaitu penambahan kapasitas Pembangkit Listrik Tenaga Panas Bumi (PLTP) hingga mencapai 9.500 MW pada tahun 2025 (ESDM, 2009).

Salah satu kendala yang banyak dihadapi dalam pengembangan energi panas bumi saat ini adalah letaknya yang terisolir jauh dari beban, sehingga menyebabkan tingkat keekonomianya kurang menarik. Namun dengan adanya harga minyak yang terus merangkak naik, dimana saat ini telah mencapai lebih dari 100 USD/barel, maka pengembangan panas bumi khususnya untuk skala kecil perlu diperhitungkan guna mengurangi subsidi pemerintah.

Dalam hal pencemaran udara, emisi dari PLTP sangat rendah bila dibandingkan dengan minyak dan batubara. Karena emisinya yang rendah, energi panas bumi memiliki kesempatan untuk dikembangkan dengan memanfaatkan pendanaan dengan skema Clean Development Mechanism (CDM).

\section{METODOLOGI}

Studi ini dilakukan untuk mengetahui biaya pembangkitan dari PLTP skala kecil. Yang dimaksud pembangkit skala kecil adalah pembangkit yang mempunyai kapasitas di bawah $5 \mathrm{MW}$.

Dalam menentukan biaya pembangkitan ini hal pokok yang menjadi pertimbangan adalah biaya pengembangan lapangan panas bumi dan biaya investasi dan Operasional \& Perawatan untuk pembangkit listrik. Dengan mempertimbangkan biaya tersebut dapat dihitung perkiraan harga listrik dari PLTP.

Untuk mencapai sasaran studi, dilakukan pengumpulan data kemudian dianalisa dengan cara pendekatan kualitatif. Pendekatan kualitatif meliputi analisis dan evaluasi berdasarkan kepustakaan dan asumsi yang sejalan dengan hasil survei mengenai data lapangan dan regulasi pengembangan panas bumi.
Dalam menghitung biaya pembangkitan PLTP skala kecil ini digunakan tiga skenario yang dianalisis untuk melihat keekonomian PLTP dengan berbagai kondisi. Skenario pertama adalah Business as Usual (BAU) yang hanya mempertimbangkan kondisi keekonomian saat ini. Skenario kedua adalah skenario dengan mempertimbangkan adanya Tingkat Kandungan Dalam Negeri (TKDN) dan skenario ketiga adalah skenario dengan skema pendanaan melalui CDM.

Adapun alur pemikiran dari tulisan ini dapat digambarkan sebagai berikut:

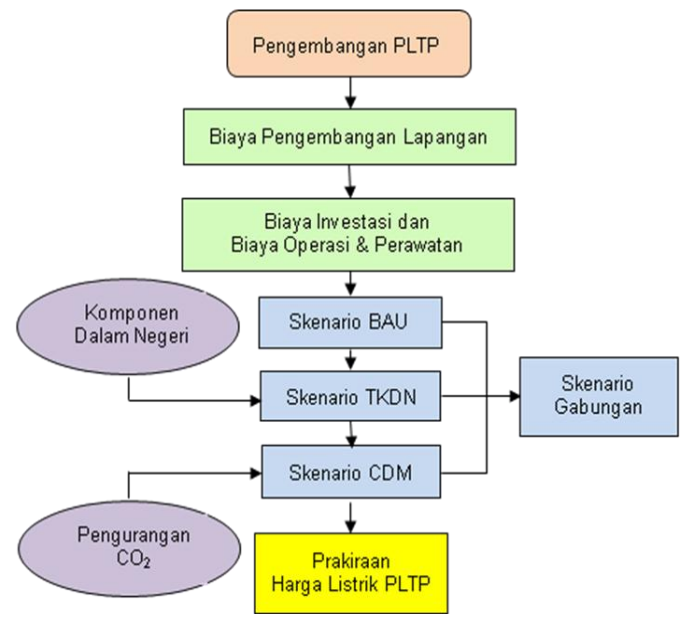

Gambar 1. Alur pemikiran perhitungan biaya pembangkitan PLTP skala kecil

\section{HASIL DAN PEMBAHASAN}

\subsection{Biaya Pembangkitan PLTP Skala Kecil}

Biaya dalam pembangunan PLTP terdiri atas 2 komponen yaitu biaya investasi/modal dan biaya operasional dan perawatan yang terdiri atas beberapa bagian yaitu:

A. Biaya Investasi/Modal

1. Biaya Eksplorasi
a. Survei pendahuluan
b. Eksplorasi rinci
c. Studi kelayakan

2. Biaya pengembangan lapangan uap (steam field), terdiri atas:

a. Biaya pemboran sumur (sumur eksplorasi, pengembangan, injeksi, make up)

b. Biaya lahan, jalan, persiapan Iahan dan lain-lain

c. Biaya fasilitas produksi

d. Biaya sarana pendukung

3. Biaya pembangkit listrik

B. Biaya Operasional dan Perawatan

1. Biaya pemeliharaan lapangan uap

2. Biaya pembangkit listrik. 
Di bawah ini akan dijelaskan lebih rinci tentang dua komponen biaya tersebut.

\subsubsection{Biaya Investasi/Modal}

Biaya investasi/modal dapat dikelompokkan menjadi dua, yaitu biaya modal langsung dan biaya modal tidak langsung.

\section{a. Biaya Modal Langsung}

Biaya modal langsung terdiri atas biaya eksplorasi, biaya pengembangan lapangan uap (steam field), dan biaya pembangkit. Dengan meningkatnya kapasitas pembangkit, biaya yang dibutuhkan untuk pengembangan PLTP (per satuan kapasitas) akan menjadi lebih kecil, sebagaimana ditunjukkan pada Gambar 2.

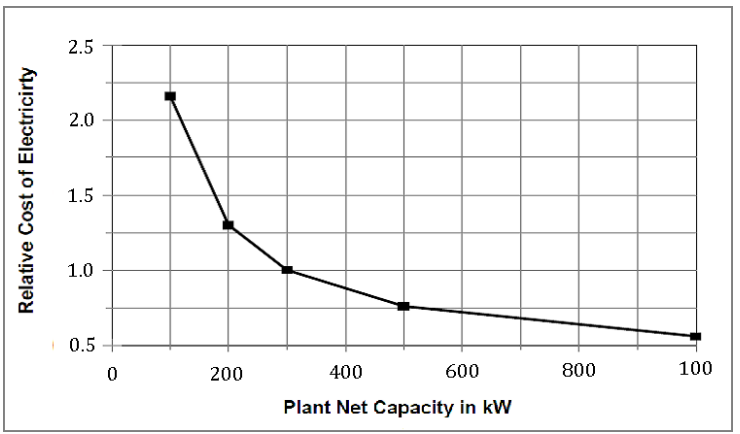

Gambar 2. Pengaruh Kapasitas Terhadap Biaya Pembangkitan PLTP (BPPT, 2011)

Al-Dabbas (2009) melakukan perhitungan biaya modal langsung seperti yang terdapat dalam Tabel 1 yang menunjukkan biaya modal langsung indikatif (US\$/kW) dalam nilai US dolar tahun 2009.

Tabel 1. Biaya Modal Langsung Berdasarkan Kualitas Sumberdaya pada Harga Konstan US\$ 2009

\begin{tabular}{|c|l|c|c|}
\hline \multirow{3}{*}{ Jenis Pembangkit } & \multicolumn{1}{|c|}{ Biaya } & $\begin{array}{c}\text { Sumberdaya } \\
\text { Kualitas Tinggi }\end{array}$ & $\begin{array}{c}\text { Sumberdaya } \\
\text { Kualitas Sedang }\end{array}$ \\
\cline { 2 - 4 } & & US\$ 2009/KW & US\$ 2009/KW \\
\hline $\begin{array}{c}\text { Pembangkit Kecil } \\
(<5 \mathrm{MW})\end{array}$ & Eksplorasi & $\$ 1000-\$ 2000$ & $\$ 1000-\$ 2500$ \\
\cline { 2 - 4 } & Lapangan Uap & $\$ 250-\$ 500$ & $\$ 750-\$ 1500$ \\
\cline { 2 - 4 } & Pembangkit & $\$ 2750-\$ 3250$ & $\$ 2750-\$ 3500$ \\
\cline { 2 - 4 } & Total & $\$ 4000-\$ 5750$ & $\$ 4500-\$ 7500$ \\
\hline $\begin{array}{c}\text { Pembangkit Sedang } \\
(5-30 \mathrm{MW})\end{array}$ & Eksplorasi & $\$ 625-\$ 1000$ & $\$ 625-\$ 1500$ \\
\cline { 2 - 4 } & Lapangan Uap & $\$ 500-\$ 1250$ & $\$ 1000-\$ 1750$ \\
\cline { 2 - 4 } & Pembangkit & $\$ 2125-\$ 3000$ & $\$ 2375-\$ 3000$ \\
\cline { 2 - 4 } & Total & $\$ 3250-\$ 5250$ & $\$ 4000-\$ 6250$ \\
\hline $\begin{array}{c}\text { Pembangkit Besar } \\
(>30 \text { MW })\end{array}$ & Eksplorasi & $\$ 250-\$ 1000$ & $\$ 250-\$ 1000$ \\
\cline { 2 - 4 } & Lapangan Uap & $\$ 750-\$ 1125$ & $\$ 750-\$ 1750$ \\
\cline { 2 - 4 } & Pembangkit & $\$ 1875-\$ 2750$ & $\$ 2125-\$ 2750$ \\
\cline { 2 - 4 } & Total & $\$ 2875-\$ 4375$ & $\$ 3375-\$ 5500$ \\
\hline
\end{tabular}

Sumber: Al-Dabbas, 2009

Sementara itu, menurut PLN (2009), biaya modal untuk pembangkit panas bumi berkisar antara 2,8 - 3,0 juta US\$/MW.
Tabel 2. Biaya Modal Pembangkit Panas Bumi

\begin{tabular}{|l|c|}
\hline \multicolumn{1}{|c|}{ Jenis Biaya } & $\begin{array}{c}\text { Total Biaya } \\
\text { (dalam juta USD/MW) }\end{array}$ \\
\hline G\&G studies, Exploration \& Development Drilling & $1,1-1,2$ \\
\hline Pipelines - Steam Above Ground System (SAGS) & 0,4 \\
\hline Power Plant, inc. Engineering \& Project Management & $1,3-1,4$ \\
\hline Total Biaya Pengembangan & $2,8-3,0$ \\
\hline
\end{tabular}

Sumber: PLN, 2009

\section{b. Biaya-Biaya Tidak Langsung}

Besarnya biaya-biaya tidak langsung sangat bervariasi bergantung pada lokasi pembangunan, aksesibilitas, tingkat infrastruktur dan kebutuhan tenaga dari luar daerah. Besarnya biaya tidak langsung tergantung pada tipe lokasi, yaitu:

- Lokasi A adalah daerah proyek di negara maju, mempunyai infrastruktur yang baik, tersedia tenaga terampil dan mempunyai fasilitas pelabuhan serta dekat dengan kota besar. Biaya tidak langsungnya berkisar antara $5-10 \%$ dari biaya langsung.

- Lokasi B adalah daerah proyek di lokasi yang lebih terpencil dari suatu negara maju, atau berada di area negara berkembang dimana infrastruktur dalam keadaan baik, memiliki sejumlah tenaga terampil dan stabilitas politik dan sosial terjaga. Biaya tidak langsungnya berkisar antara $10-30 \%$ dari biaya langsung.

- Lokasi C adalah daerah proyek yang berada di lokasi yang sangat terpencil dari suatu negara berkembang, mempunyai infrastruktur yang kurang baik, aksesibilitasnya sulit, tenaga terampil langka dan memiliki resiko ketidakstabilan politik. Biaya tidak langsungnya berkisar antara $30-60 \%$ dari biaya langsung.

\subsubsection{Biaya Operasi dan Pemeliharaan}

Biaya operasi dan pemeliharaan pada proyek panas bumi dibagi menjadi dua bagian, yaitu biaya operasi dan pemeliharaan lapangan uap dan pembangkit listrik. Besarnya biaya operasi dan pemeliharaan ditunjukkan dalam Tabel 3

Tabel 3. Biaya Operasi dan Pemeliharaan pada Harga Konstan US\$ 2009

\begin{tabular}{|c|c|c|c|}
\hline \multirow{2}{*}{ Komponen Biaya } & $\begin{array}{c}\text { Pembangkit Kecil } \\
(<5 \text { MW) }\end{array}$ & $\begin{array}{c}\text { Pembangkit Sedang } \\
(5-30 \text { MW })\end{array}$ & $\begin{array}{c}\text { Pembangkit Besar } \\
(>30 \text { MW })\end{array}$ \\
\cline { 2 - 4 } & US 2009 cents/kWh & US 2009 cents/kWh & US 2009 cents/kWh \\
\hline Lapangan Uap & $0,875-1,75$ & $0,625-0,875$ & $0,375-0,625$ \\
\hline Pembangkit & $1,125-1,75$ & $0,875-1,125$ & $0,625-1,125$ \\
\hline Total & $\mathbf{2 , 0 - 3 , 5}$ & $\mathbf{1 , 5 - 2}$ & $\mathbf{1 , 0 - 1 , 7 5}$ \\
\hline
\end{tabular}

Sumber: Al-Dabbas, 2009

Biaya-biaya tersebut tidak termasuk biaya pembuatan sumur-sumur baru, yang biasanya dibutuhkan dengan waktu untuk menggantikan 
produksi yang berangsur-angsur merosot dari sumur-sumur yang asli. Laju penurunan produksi sumur-sumur panas bumi tergantung pada sifat alami sumber daya dan ukuran pengembangan, tetapi biasanya dapat bervariasi antara $5 \%$ hingga $10 \%$ tiap tahun. Oleh karena itu, sebagai tambahan terhadap biaya-biaya tersebut, suatu pengembang harus mempertimbangkan sekitar $8 \%$ dari total biaya-biaya sumur tiap-tiap tahun untuk kebutuhan sumur pengganti di masa datang (BPPT, 2011).

\subsection{Skenario Finansial}

Berdasarkan data-data yang telah dikumpulkan kemudian dilakukan perhitungan biaya pembangkitan PLTP skala kecil. Untuk menghitung biaya pembangkitan diperlukan data yang rinci seperti pada Tabel 4.

Tabel 4. Parameter Input Data

\begin{tabular}{|l|c|c|}
\hline \multicolumn{1}{|c|}{ Parameter } & Simbol & Unit \\
\hline Faktor Ketersediaan & Avail & $\%$ \\
\hline Umur Ekonomis & Tekonom & Tahun \\
\hline Lama Pembangunan & Tkonst & Tahun \\
\hline Investasi Domestik & LC & US \$/kW \\
\hline Biaya O\&M & OM & US $\$ /$ kWhy \\
\hline Discount Rate & DiscRate & $\%$ \\
\hline Disbursement Domestik & Dlc $_{\boldsymbol{i}}$ & $\%$ \\
\hline
\end{tabular}

Rumus perhitungan yang digunakan adalah sebagai berikut:

$$
\begin{aligned}
& \text { Avail }=\frac{A v}{100} \\
& \text { DisL } C_{i}=\frac{D L c_{i}}{100} \\
& d=\frac{\text { DiscRate }}{100} \\
& \text { FdLC }=\sum_{i=1}^{\text {Tkonsty }}\left(\text { DisLc } c_{i} \times(1+d)^{\text {Tkonst-i+0.5 }}\right) \\
& \text { Cost }=(F d L C \times L C) \\
& F P M=\frac{d \times(1+d)^{\text {Tekonom }}}{(1+d)^{\text {Tekonom }}-1}
\end{aligned}
$$

$$
\text { Biaya Pembangkit }=\frac{F P M \times C o s t}{\text { Avail } \times 8,760}+O M
$$

Besarnya biaya investasi dipengaruhi oleh dua parameter penting yaitu kualitas sumber daya dan kondisi infrastruktur di lokasi tersebut.

Tabel 5. Data Investasi (US\$2009 $/ \mathrm{kW}$ )

\begin{tabular}{|c|r|r|r|r|r|r|}
\hline \multirow{2}{*}{$\begin{array}{c}\text { Tipe } \\
\text { Lokasi }\end{array}$} & \multicolumn{6}{|c|}{ Kualitas Sumber Daya } \\
\cline { 2 - 7 } & \multicolumn{2}{|c|}{ Tinggi } & \multicolumn{2}{c|}{ Menengah } & \multicolumn{2}{|c|}{ Rendah } \\
\cline { 2 - 7 } & \multicolumn{1}{|c|}{ Min } & \multicolumn{1}{|c|}{ Max } & \multicolumn{1}{c|}{ Min } & \multicolumn{1}{c|}{ Max } & \multicolumn{1}{c|}{ Min } & \multicolumn{1}{c|}{ Max } \\
\hline Maju & 4.2 & 6.325 & 4.725 & 8.25 & 5.25 & 10.175 \\
\hline Sedang & 4.4 & 7.475 & 4.95 & 9.75 & 5.5 & 12.025 \\
\hline Terpencil & 5.2 & 9.2 & 5.85 & 12 & 6.5 & 14.8 \\
\hline
\end{tabular}

Sumber: Sugiyono, 2012

Dalam menghitung biaya pembangkitan PLTP skala kecil ini, digunakan asumsi discount rate $10 \%$, umur ekonomis 25 tahun dan faktor ketersediaan 95\%. Sedang lamanya waktu eksplorasi, eksploitasi sampai pembangunan pembangkit diasumsikan memerlukan waktu selama 2 tahun. Biaya operasi dan perawatan ditunjukkan pada Tabel 6.

Tabel 6. Biaya Operasi dan Perawatan

\begin{tabular}{|c|c|c|}
\hline \$/kWh/tahun & Min & Max \\
\hline Biaya Operasi \& Perawatan & 2,00 & 3,50 \\
\hline
\end{tabular}

Sumber: Sugiyono, 2012

\subsubsection{Skenario Bussiness as Usual}

Skenario Business as Usual (BAU) diasumsikan bahwa biaya pembangkitan hanya tergantung dari komponen biaya investasi serta komponen biaya operasi dan perawatan, Dengan menggunakan data dan rumus di atas, biaya pembangkitan PLTP untuk skenario BAU ini ditunjukkan pada Tabel 7 .

Tabel 7. Hasil Perhitungan Biaya Pembangkitan (cent $\$ / \mathrm{kWh}$ )

\begin{tabular}{|c|r|r|r|r|r|c|}
\hline \multirow{2}{*}{ Tipe Lokasi } & \multicolumn{6}{|c|}{ Kualitas SDA } \\
\cline { 2 - 7 } & \multicolumn{2}{|c|}{ Tinggi } & \multicolumn{2}{c|}{ Menengah } & \multicolumn{2}{c|}{ Rendah } \\
\cline { 2 - 7 } & Min & Max & Min & Max & Min & Max \\
\hline Maju & 90,560 & 141,260 & 99,380 & 173,600 & 108,200 & 205,940 \\
\hline Sedang & 93,920 & 160,580 & 103,160 & 198,800 & 112,400 & 237,020 \\
\hline Terpencil & 107,360 & 189,560 & 118,280 & 236,600 & 129,200 & 283,640 \\
\hline
\end{tabular}

Dari hasil perhitungan terlihat bahwa biaya pembangkitan PLTP skala kecil berkisar antara 9,056 cent $\$ / k W h$ sampai dengan 28,364 cent $\$ / \mathrm{kWh}$. Bila biaya tersebut dirata-rata maka biaya pembangkitannya adalah 15,50 cent $\$ / \mathrm{kWh}$.

Semakin rendah kualitas sumber daya maka biaya pembangkitan PLTP semakin mahal. Begitu juga untuk kondisi infrastruktur di lokasi PLTP, biaya pembangkitan akan mahal jika infrastruktur di lokasi tersebut tertinggal. 


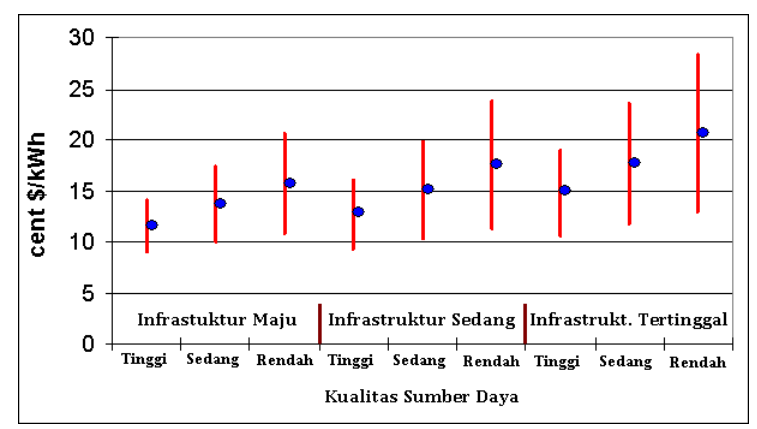

Gambar 3. Biaya Pembangkitan PLTP Skala Kecil (Sugiyono, 2012)

\subsubsection{Skenario TKDN}

Semakin tinggi komponen dalam negeri dalam pembangunan PLTP diharapkan harga listrik PLTP dapat lebih murah.

Kandungan Dalam Negeri (KDN) untuk barang PLTP skala kecil (3 MW) saat ini adalah $48,5 \%$, sementara untuk Jasa PLTP sebesar $97,3 \%$. Dengan bobot masing-masing komponen tersebut 0,7 dan 0,3, maka TKDN untuk barang PLTP mencapai $34,0 \%$ sedangkan untuk jasa sebesar $29,2 \%$ atau total TKDN untuk barang dan jasa PLTP skala kecil sebesar $63,14 \%$. Nilai ini lebih tinggi dari TKDN yang diperhitungkan oleh Kementrian Perindustrian untuk PLTP kapasitas < $10 \mathrm{MW}$ yakni sebesar $40,45 \%$.

Tabel 8. TKDN Barang dan Jasa PLTP Skala Kecil

\begin{tabular}{|c|c|c|c|c|c|}
\hline Uraian & KDN (\%) & KLN (\%) & Bobot & TKDN (\%) \\
\hline I & Barang PLTP & $48.50 \%$ & $52.80 \%$ & 0.70 & $33.30 \%$ \\
\hline II & Jasa PLTP & $97.30 \%$ & $2.70 \%$ & 0.30 & $29.20 \%$ \\
\hline & Total Bobot & & & 1.00 & \\
\hline \multicolumn{7}{|c|}{ TKDN Barang dan Jasa PLTP 5 MW - 10 MW (\%) } & $\mathbf{6 3 . 1 5 \%}$ \\
\hline
\end{tabular}

Sumber: Nurrohim, 2015

Dengan penggunaan produksi dalam negeri maka diharapkan akan dapat mengurangi biaya investasi peralatan yang digunakan untuk PLTP. Pengurangan ini setidaknya sebesar tarif impor dari barang modal yang digunakan untuk investasi.

Meskipun dalam regulasi pemerintah memberi beberapa fasilitas atas Bea Masuk (BM), Pajak Pertambahan Nilai (PPN), Pajak Penghasilan (PPh) dan Pajak ditanggung Pemerintah ada beberapa pengecualian, yaitu fasilitas tersebut tidak diberikan ketika komponen atau barang sudah bisa diproduksi di dalam negeri.

Perhitungan dalam skenario TKDN ini tetap mengacu pada perhitungan umum yang didasarkan pada Peraturan Menteri Keuangan Republik Indonesia Nomor 213/PMK.011/2011 tentang Penetapan Sistem Klasifikasi Barang dan Pembebanan Tarif Bea Masuk Atas Barang Impor.
Adapun besarnya bea masuk, PPN dan PPh dihitung dengan persamaan sebagai berikut:

- Bea Masuk $=\mathrm{CIF}{ }^{*}$ tarif bea masuknya

$-\mathrm{PPN}=(\mathrm{CIF}+$ Bea Masuk $) * 10 \%$

$-\mathrm{PPh}=(\mathrm{CIF}+$ Bea Masuk $) * 7.5 \%$

Dimana,

$\mathrm{CIF}=$ Cost, Insurance and Fright.

yaitu, besarnya harga barang + asuransi + ongkos transportasi

Tarif bea masuk $=10 \%$ (Peraturan Menteri Keuangan Nomor 213/PMK.011/2011).

Selanjutnya, untuk perhitungan biaya pembangkitan pada skenario TKDN ini yang diperhitungkan adalah kandungan luar negeri dengan dikurangi PPN dan PPh untuk impor barang dan PPh untuk impor jasa. Dua perhitungan yang dilakukan dalam skenario ini, yaitu kondisi KLN 52,8\% untuk barang PLTP dan $2,7 \%$ untuk jasa PLTP atau yang menghasilkan total TKDN sebesar $63,14 \%$ (kondisi saat ini).

Dengan mengurangi besarnya PPN dan PPh berdasarkan tarif bea masuk yang berlaku, biaya investasi untuk TKDN sebesar $63,14 \%$ akan berkurang sebesar 679 US $\$ / \mathrm{kW}$ atau turun sebesar $8,95 \%$ dibandingkan biaya investasi pada skenario BAU. Penurunan investasi tersebut secara langsung akan menurunkan biaya pembangkitan menjadi 14,36 cent $\$ / \mathrm{kWh}$ atau berkurang sebesar $7,36 \%$ dibanding skenario BAU. Besar penurunan biaya pembangkitan untuk skenario TKDN dibandingkan skenario BAU ditunjukkan seperti pada Tabel 9.

Tabel 9. Penurunan Biaya Pembangkitan untuk Skenario TKDN

\begin{tabular}{|l|r|r|}
\hline & \multicolumn{1}{|c|}{ Biaya Investasi } & \multicolumn{1}{|r|}{ Biaya Pembangkitan } \\
\hline Satuan & US \$/kW & Cent \$/kWh \\
\hline BAU & 7,588 & 15.5 \\
\hline TKDN 63\% & 6,908 & 14.36 \\
\hline Penurunan & 679 & 1.14 \\
\hline$\%$ penurunan & 8.95 & 7.36 \\
\hline
\end{tabular}

\subsubsection{Skenario CDM}

Melalui skema CDM ini diharapkan dapat menurunkan biaya pembangkitan yang pada akhirnya harga listrik diharapkan dapat lebih murah.

Saat ini ada dua metodologi yang sudah disetujui oleh United Nations Framework Convention on Climate Change (UNFCCC) untuk pemanfaatan panas bumi dengan skema CDM, yaitu ACM0002 untuk pemanfaatan panas bumi 
untuk grid pembangkit listrik dan AM0072 untuk space heating (Matthiasdottir et.al., 2010).

Emisi $\mathrm{CO}_{2}$ dari PLTP sangat kecil jika dibandingkan dengan pembangkit dengan bahan bakar fosil. Berdasarkan CDM project design document (PDD) dari PLTP Darajat Unit III, mempunyai emisi sebesar $30 \mathrm{~kg} \mathrm{CO} / \mathrm{MWh}$, sementara emisi pembangkit berbahan bakar batubara dan minyak masing-masing sebesar 994 $\mathrm{kg} \mathrm{CO} / \mathrm{MWh}$ dan $758 \mathrm{~kg} \mathrm{CO} / \mathrm{MWh}$. Bahkan untuk PLTP binary, tidak ada emisi $\mathrm{CO}_{2}$ yang dikeluarkan (BPPT, 2011).

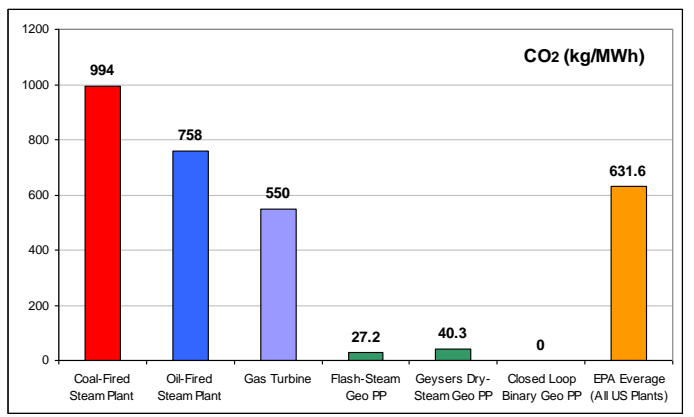

Gambar 4. Emisi $\mathrm{CO}_{2}$ Berbagai Jenis Pembangkit (DiPippo, 2008)

Ada beberapa sumber kajian lain untuk menentukan koefisien emisi $\mathrm{CO}_{2}$. Berdasarkan studi UNDP (2008) emisi $\mathrm{CO}_{2}$ dari pembangkit panas bumi di Indonesia adalah sebesar 200 $\mathrm{kg} / \mathrm{MWh}$, sedangkan rata-rata emisi $\mathrm{CO}_{2}$ dari pembangkit di Indonesia adalah $756 \mathrm{~kg} / \mathrm{MWh}$. Berdasarkan Khoirunissa et.al. (2010) emisi $\mathrm{CO}_{2}$ dari pembangkit panas bumi sebesar 27.5 $\mathrm{kg} / \mathrm{MWh}$. Perhitungan yang terakhir ini lebih mendekati hasil perhitungan DiPippo (2008).

Biaya pembangkitan PLTP di Indonesia sekitar $5,8-17$ cent $\$ / \mathrm{kWh}$ atau rata-rata sekitar 9,5 cent $\$ / k W h$. Dengan mengambil asumsi faktor kapasitas sebesar $90 \%$, emission base line untuk sistem grid $891 \mathrm{~kg} / \mathrm{MWh}$, emisi PLTP sebesar $17,7 \mathrm{~kg} / \mathrm{MWh}$ dan harga CER sebesar 10 \$/ton maka dengan skema CDM dapat mengurangi biaya pembangkitan sekitar 0,85 cent $\$ / \mathrm{kWh}$.

\subsubsection{Skenario Gabungan}

Berdasarkan perhitungan untuk berbagai skenario tersebut dapat dirangkum gambaran biaya pembangkitan PLTP skala kecil seperti ditunjukkan pada Gambar 5. Biaya pembangkitan rata-rata untuk PLTP skala kecil sebesar 15,50 cent $\$ / k W h$ untuk skenario BAU.

Dengan mempertimbangkan TKDN maka biaya pembangkitan diperkirakan akan menurun sekitar $7,36 \%$ atau sebesar 1,14 cent $\$ / k W h$ menjadi 14,36 cent $\$ / \mathrm{kWh}$.

Untuk skenario CDM maka akan dapat mengurangi biaya pembangkitan sebesar 0,85 cent $\$ / \mathrm{kWh}$ atau biaya pembangkitan menjadi sebesar 14,65 cent $\$ / k W h$.

Dengan skenario gabungan maka biaya pembangkitan menjadi sebesar 13,51 cent $\$ / \mathrm{kWh}$ atau menurun terhadap skenario BAU sebesar 1,99 cent $\$ / k W h$

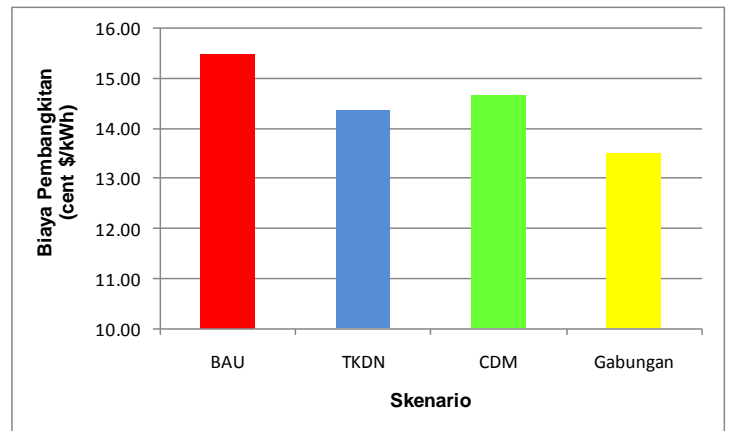

Gambar 5. Perbandingan Biaya Pembangkitan PLTP Skala Kecil

Biaya pembangkitan PLTP skala kecil bila dibandingkan dengan Pembangkit Listrik Tenaga Disel (PLTD) skala kecil masih lebih murah. Biaya pembangkitan PLTD skala kecil adalah 17, 28 cent $\$ /$ kWh (BPPT, 2011)

\section{KESIMPULAN}

Struktur biaya PLTP meliputi dua komponen yaitu biaya investasi, dan biaya operasional dan perawatan.

Letak pembangkit akan mempengaruhi biaya pembangkitan PLTP. Letak yang terisolir jauh dari beban, menyebabkan tingkat keekonomian PLTP kurang menarik.

Besarnya biaya investasi dipengaruhi oleh kualitas sumber daya dan kondisi infrastruktur di lokasi PLTP.

Biaya pembangkitan rata-rata untuk PLTP skala kecil sebesar 15,5 cent $\$ / \mathrm{kWh}$ untuk skenario BAU, 14,36 cent $\$ / \mathrm{kWh}$ untuk skenario TKDN, 14,65 cent $\$ / \mathrm{kWh}$ untuk skenario CDM dan 13,51 cent $\$ / k W h$ untuk skenario gabungan.

Biaya pembangkitan PLTP skala kecil lebih murah dibanding dengan PLTD skala kecil, dimana biaya pembangkitan PLTD skala kecil adalah 17,28 cent $\$ / \mathrm{kWh}$.

\section{DAFTAR PUSTAKA}

Sugiyono, Agus. (2012) Keekonomian Pengembangan PLTP Skala Kecil, Seminar Nasional Teknik Kimia Indonesia dan Musyawarah Nasional APTEKINDO 2012.

Al-Dabbas, M.A.A. (2009) The Economical, Environmental and Technological Evaluation of Using Geothermal Energy, European 
Journal of Scientific Research, Vol.38 No.4 pp 626-642, Euro Journals Publishing, Inc.

BPPT (2011) Studi Keekonomian, TKDN dan CDM PLTP Skala Kecil di Indonesia

DiPippo, Ronald (2008) Geothermal Power Plants: Principles, Applications, Case Studies and Environmental Impact, Second Edition, Elsevier.

Khoirunissa, I., Agani, M., Utomo, I.S., and Setiawan, A.T. (2010) Clean Development Mechanism (CDM) Project for Kamojang Unit 4 Geothermal Power Plant, Proceedings World Geothermal Congress, Bali.

Matthiasdottir, K.V., Olafsson, E., and Gislason, T. (2010) Impact of the Clean Development Mechanism on Geothermal Development, Proceedings World Geothermal Congress, Bali.

Nurrohim, Agus. (2015) Pengaruh TKDN pada Biaya Pembangkitan Listrik Panas Bumi Skala Kecil, Jurnal Energi dan Lingkungan, Pusat Teknologi Pengembangan Sumber Daya Energi - BPPT, Jakarta, Vol 11 No. 1 Juni 2015, HIm 33-40.

Sakya, I.M.R. (2009) Pemanfaatan Teknologi Panas Bumi di Indonesia, PT PLN (Persero), disampaikan pada Seminar Geotermal dan Biofuel sebagai Sumber Energi Masa Depan Terbarukan dan Ramah Lingkungan, Universitas Gunadarma, 23 Nopember 2009.

Shibaki, M. (2003) Geothermal Energy for Electric Power, A REPP Issue Brief, Renewable Energy Policy Project, Washington, DC. 